\title{
NOTES
}

\section{“I DIDN'T LIKE HIS BOOKS": JULIAN HAWTHORNE ON WHITMAN}

The son of Nathaniel and Sophia Hawthorne, Julian Hawthorne (1846-1934) would have been a public intellectual had he been an intellectual. Instead, he was a literary gadfly, content to eke out a living by exploiting his family name and courting controversy by exposing the private peccadillos of such public figures as Margaret Fuller and James Russell Lowell. ${ }^{1}$ As Fuller's nephew later lamented, Hawthorne was "not one to spoil a sensation to save a friend." ${ }^{2}$ His inclination to smash literary idols is evident, too, in his comments about Walt Whitman over the years.

Hawthorne was not always critical of the poet. As early as 1885 he praised Whitman, Mark Twain, and other non-New Englanders for their freedom "from any Boston taint." 3 In a series of articles and reviews between 1887 and 1889 , he repeatedly hailed Whitman's courage and defiant spirit. His ideas have "immense independent value," he announced, and while Hawthorne did not "pretend to solve Walt Whitman," he believed "that those who honor him most highly are the ones who best understand him.". "We owe a debt of gratitude to Walt Whitman," he elsewhere declared, "not because he rebelled in the right direction, but because he rebelled at all. He proved that the thing could be done, and there is great moral help in that." ${ }^{5} \mathrm{He}$ compared Whitman to Zola in his willingness to test the limits of expression and prove "that the system of repression is more injurious to human nature than the most unrestricted free speech and action can be." ${ }^{\prime 6}$ Hawthorne attended Whitman's seventieth birthday celebration in Camden on May 30, 1889, and delivered a brief tribute:

Walt Whitman sits here as the deputy of nature, her embassador [sic] accredited and approved. I have always thought of Walt Whitman less as an individual man than as a gospel. Praise of him is praise of humanity, and personal vanity is as alien from him as from Mt. Washington or the Mississippi .... His books show us that no one better than he has loved his fellow-man.

Hawthorne alluded to Whitman's affection for "the greatest man of our generation, Abraham Lincoln," as well as for the forlorn streetwalker in such poems as "O Captain! My Captain!" and "To a Common Prostitute." "Surely, the man and poet whose sympathy can extend from the highest specimen of our times to the lowest nameless outcast," he concluded, "is worthy of more than all the sympathy and honor that we contain." ${ }^{7}$ When Whitman died almost three years later, Hawthorne was selected to serve as one of the pallbearers. ${ }^{8}$

Unfortunately, the story of his regard for Whitman does not end here. Hawthorne betrayed increasing disgust with the "innovators" (as he called them) as he grew older. Never much of a democrat, he became ever more a literary 
snob. Commissioned to write one of the first American literature textbooks, Hawthorne chose to bury Whitman rather than to praise him. The poet, he now asserted, was only superficially an "innovator," his "revolt" little more than a confidence game, his admirers nothing more than dupes.

Much of his apparent originality is due to his remarkable ignorance; he knows almost nothing of the thought and history of mankind; and the coarse, primitive quality of his intellect renders him incapable of receiving cultivation. His egotism is at least commensurate with his ignorance; and the world, startled at the magnitude of his pretensions, and perplexed by the turgid and uncouth truculence of his diction, accepted him, for a time - and pending further inquiry — at his own valuation.

Whitman's "claim to credit for inventing a new poetic style," Hawthorne added, "will not bear serious examination." He also attacked the poet's early writing, informing readers that, prior to the publication of Leaves of Grass, Whitman "had attempted to write according to the ordinary rules and had failed to attract notice, the reason being that he was incompetent, owing to deficiency of mental equipment, to yield intelligent obedience to the laws of composition, prose and metrical."

Because Whitman "could not use the instruments that sufficed for Homer, Shakespeare and Tennyson," according to Hawthorne, "he bethought himself to decry these as effete and inadequate and to bray forth his message upon a fog-horn." He was so deaf to the music of poetry that he failed to

distinguish between the lofty harmonies of the Old Testament and that mixture of the double-shuffle and the limp, the stride and the break-down, that he offers to us as the poetry of the future.... In proclaiming a revolt gainst the errors and prejudices of the past, he succeeded only in revolting against good taste, common sense and literary sanity. Instead of resonance, eloquence and the irregular but sublime rhythm of nature - of the cataract, the sea, the wind in the boughs of the primeval forest - he gives us the slang of the street, the patois and pigeon English of the frontier, and the bald vulgarity of the newspaper penny-a-liner. In short, there is not one word to be said in defence of the medium through which Whitman declares himself.

His champions, on the other hand, were mere slaves to fashion:

In old times a sort of sanctity and reverence was associated with idiots, insane persons and victims of hysteria and epilepsy. Analogous to this is the attitude of many of Whitman's admirers and disciples today. They cannot persuade themselves that a man who acts so grotesquely should be anything less than inspired. If he cut his hair, dressed respectably, spoke in hexameters and in good grammar, they would not bestow a second thought upon him.

In all, Whitman was merely a "fad-the pet-of the aristocracy of culture; and when they have tired of him, he will be in danger of slipping out of sight altogether." So much for Hawthorne's critical judgment and prescience. 
He praised only one of Whitman's verses in his textbook - predictably, again, "O Captain! My Captain!" Occasionally, he conceded, when the poet's "feelings are strongly affected (as on the occasion of the assassination of Lincoln) the very clumsiness and inertia of his mind operates to give a lyrical quality to his utterance." "O Captain!" is "a genuine and moving poem" largely because "it runs counter to every principle that Whitman has laid down as binding upon the poet. The lines are rhymed and regular, the theme is purely personal, the language is direct and simple, and even the grammar is comparatively orthodox." It was an example of the poetry Whitman might have written had he "forgotten himself and his philosophy."

The textbook was first published in 1891, a few months before Whitman's death, but Horace Traubel did not read Hawthorne's critique until 1896. To his credit, Traubel offered a couple of possible explanations for the inconsistencies between Hawthorne's tribute to Whitman in Camden in 1889 and his denunciation of him in 1891. Hawthorne may not have been "individually responsible for the opinions which appear" in the book because he "sold his name unconditionally and simply" to the publisher and so "had nothing to do with the preparation of the manuscript." Or perhaps he simply "changed his mind." 10

Characteristically, Hawthorne responded without a modicum of tact. In a letter to the editor of the Conservator, he denied categorically that he had sold his name or signed off on what others had written. Every word in the textbook "and every opinion it expresses," he insisted, "is my own word and my own opinion; I wrote the volume, independently, from beginning to end." Nor did he even admit there were contradictions between the two texts, though he allowed that in Camden he had spoken "on the spur of the moment, and in circumstances where the speaker would naturally strain a point to be in harmony with the geniality of the occasion. ... But when he sits down to write a criticism, he is bound to tell the whole truth as he sees it."

On his part, Traubel replied by annotating Hawthorne's denial. He did not "intend to enter into any controversy with Mr. Hawthorne as to the truth of his literary judgments." Still, "I insist that there is entire inconsistency" between Hawthorne's speech and his textbook. "Hawthorne confesses this in fact when, after saying the two statements do not contradict each other, he proceeds to explain one of them away." Traubel also noted that Hawthorne had received a copy of his comments in Camden in proof several weeks after the dinner and could have revised his remarks prior to their publication in Camden's Compliment to Walt Whitman. Better yet, Hawthorne might simply have allowed that he had changed his mind: "I would much rather he could honestly have said that when he spoke in Camden he believed what he then said and when he wrote in the book he believed what the book projected." And then Traubel's blunt conclusion: "I believe in untrammeled opinion. I congratulate Mr. Hawthorne upon his untrammeled book. I wish he had been untrammeled when he sat near Whitman in Camden in 1889."11

Lamentably, Hawthorne never again expressed a favorable opinion of Whitman. He was too wedded to tradition and/or too fond of controversy and/or too devoted to a sentimentalized ideal of middle-class, heterosexual marriage. Though he reprinted a pair of brief excerpts, totaling about forty lines, from 
"Song of Myself" and "The Mystic Trumpeter," in his ten-volume anthology The Literature of All Nations and All Ages (1897-1898), as well as the whole of Whitman's Preface to the 1855 Leaves of Grass in his co-edited Essays of American Essayists (1900), ${ }^{12}$ he returned to offense in his review of E. C. Stedman's $A n$ American Anthology, 1787-1899 (1900). Stedman had foolishly placed Emerson, Poe, and Whitman "all between the same covers," according to Hawthorne, with most of the attention devoted to "the great American hog of letters, wallowing, swilling and grunting in mud and straw." Hawthorne ridiculed "the consideration professed for this hairy lubber by men of light and leading in our generation." He then fired a gratuitous shot at Traubel for recently enshrining "Oscar Wilde as the twin god of his idolatry"13 - this less than a year after Wilde's death and only five years after his arrest and imprisonment for "gross indecency." Much as he had attacked Fuller in 1884 for her alleged fornication, Julian Hawthorne derided Whitman after 1891 for his unconventional private life. His domestic ideal was epitomized by the idyllic marriage of his parents, at least as he represented it, as the title of his 1927 essay may suggest: "Such is Paradise: The Story of Sophie and Nathaniel Hawthorne." ${ }^{14}$ Whitman clearly did not rise to this ideal.

Hawthorne twice devoted his weekly column in the Pasadena Star-Newspublished in the newspaper for thirteen years in the 1920s and 1930s-to reminiscences of Whitman. In October 1925, he opined that the "cheery old ragamuffin" was "never of quick intelligence; he was, on the contrary, rather inclined to the bovine," a sacred cow to his admirers. With "no understanding of form, no instinct for rhythm," he wrote "lawless verse" that was nothing more than "a huge bluff, and bluff wins nine times out of ten." A third of a century afterWhitman's death, Hawthorne also resorted to ad hominem attack: "My personal contacts with Walt Whitman were few, and I don't think he sought them: I am sure I didn't. I didn't like his books. He was not immaculate in his bodily condition, and though he spoke in a burly way, I never heard him say anything worth the saying." Hawthorne remembered attending Whitman's seventieth birthday celebration in Camden, but in a decidedly unflattering way:

One evening . . J Joe Stoddart, editor of Lippincott's, with whom I was staying in Philadelphia, had to attend a dinner given to Walt in Camden, and insisted on my going too. There were some fifty guests at the long table, Walt at the head, supported by Horace Traubel on one side and some other domestic on the other. Walt sprawled, wagged his beard, chuckled, drank and yawped in good prophetic style, and ever and anon called out to one or another guest to "come on" and testify.

In this version of events, Hawthorne's presence at the dinner was sheer happenstance. ${ }^{15}$

In April 1933, a year before his death at age eighty-eight, Hawthorne recorded his final impressions of Whitman. Again he ridiculed the "cockcrow idolators" who worshipped the poet, and again he engaged in ad hominem attack: 
Whitman became notorious without popularity, and died in the conviction he was a second Isaiah. . . . His intellect was immature and probably diseased. He was personally unclean and smelt so, so that his female attendants would every morning swab off a space on the right-side of his forehead, for the girl acolytes to kiss him on.

He added a new crime to his list: Whitman was allegedly a homosexual. At least the poet had been "charged with such indiscretions as sufficed to send Oscar Wilde to jail." Rather than a champion of free expression, Whitman was, in this view, a decadent responsible for the undiapering of American letters. Before his death, Hawthorne wrote, the poet had removed "some safety pins" from "our American literature."16

Over the course of half a century, Julian Hawthorne had completely reversed his opinion. Ironically, as keeper of the family flame, he ardently defended the reputation of his parents and scorned debunking biographers to the end of his life. He might have removed the beam from his own eye before he tried to remove the mote in others.

University of New Mexico

GARY SCHARNHORST

\section{NOTES}

1 Thomas R. Mitchell, "Julian Hawthorne and the 'Scandal' of Margaret Fuller," American Literary History 7 (Summer 1995), 210-233; George Knox, "The Hawthorne-Lowell Affair," New England Quarterly 29 (December 1956), 493-502.

2 Frederick T. Fuller, "Hawthorne and Margaret Fuller Ossoli," Literary World (January 10, 1885), 11-15.

3 "Is Boston Losing Its Literary Prestige?" Brooklyn Magazine 3 (December 1885), 93.

4 "Literature of the Day," New York World (January 16, 1887), 11.

5 "Literature in Masquerade," America (April 7, 1888), 7.

6 "The Business of Life," America (April 4, 1889), 22. See also "Literature," American Magazine 7 (November 1887), 107; "Book Reviews," Bookmart 6 (October 1888), 280; "Book Reviews," Bookmart 6 (November 1888), 342; and "Magazines versus Literature," Brains (September 15, 1891), 45.

7 "Deputy of Nature," in Camden's Compliment to Walt Whitman, ed. Horace L. Traubel (Philadelphia: David McKay, 1889), 39-40.

8 "Ingersoll to Whitman," Baltimore Sun (March 29, 1892), 1.

9 Julian Hawthorne with Leonard Lemmon, American Literature:An Elementary Textbook (Boston: D. C. Heath, 1891), 261-265.

10 Horace Traubel, "Julian Hawthorne's Several Opinions of Walt Whitman," Conservator 7 (November 1896), 136-137. 
11 Julian Hawthorne, "Hawthorne-Lemmon on American Literature," Conservator 7 (December 1896), 151-152.

12 The Literature of All Nations and All Ages: History, Character, and Incident (Philadelphia: Finley, 1897-1898), X, 334-336; Essays of American Essayists (New York: Colonial Press, 1900), 401-415.

13 "Books and Their Makers," Philadelphia North American (January 28, 1901), 13. These comments were also posthumously reprinted in Hawthorne's column "A Note on Anthologies," Pasadena Star-News (October 3, 1934), 11. See also "The Desire for Truth," Booklover's Weekly (November 25, 1901), 115: "Walt Whitman founded a sect, and established a fashion in what he was pleased to call poetry, because the rugged and often repulsive nakedness of his speech was thought to mean that he was a sincerer truth-teller than others.”

\section{Century 93 (December 1927), 157-169.}

15 "Walt Whitman," Pasadena Star-News (October 28, 1925), 8. See also "When Gilder Was Pooh-bah," Pasadena Star-Nerws, (August 17, 1929), 36: "the American bard, Walt Whitman, with scraps of paper covered with pencil scribblings in his pocket, to be interpreted into 'Leaves of Grass' at editorial conferences; a vague, wandering, childlike prophet, open of collar, threadbare of coat, dingy of shirt, shaggy of hair and beard; vain, timid, orphic and ordinary."

16 "Whitman and the Moderns / Some Notes on Critics, Poets, Novelists, Norman Foerster and American Criticism," Pasadena Star-News, (April 29, 1933), 15.

\section{AN ECUADORIAN WHITMAN POEM}

The poetry of Ecuadorian Roy Sigüenza (b. 1958) is homoerotic in theme and terse in expression. He generally focuses on scenes of daily life in ordinary places, transforming a movie house or a park bench into a setting for an erotic encounter. Despite his preference for brevity and simplicity of language, at times he makes use of greater stylization, while including references to other homosexual writers from both Europe and the United States. Within the Ecuadorian poetic scene, Sigüenza, speaking with a new lyric voice (that of a marginalized and persecuted homosexual), has developed a style that, very quickly, other poets have adopted as a reference point for their own work. One of the few authors in Ecuador willing to write of marginalized sexual experiences in an openly confessional manner, he has gained a certain status as a literary rebel in his own country. It is not surprising, then, that he would be attracted to Walt Whitman, whom he invokes in this modest little poem from his book Ocupate de la noche (Cuenca, 2000). I recently translated this poem with Fernando Iturburu; this is the first appearance of Sigüenza in an English translation.

Pista de baile

Aunque prefiera la danza Cheyenne, el vals le va a $\mathrm{Mr}$. Whitman 